\title{
Mamanda theatre, the play of Banjar culture
}

\author{
NINUK KLEDEN-PROBONEGORO
}

\begin{abstract}
This article reveals the dialectic relationship between Teater Mamanda and the living conditions of Banjarese community. When we watch Mamanda, we watch the life and culture of the Banjarese. Without any knowledge of Banjarese society and culture we cannot possibly understand the content of a Mamanda performance as a miniature version of Banjarese society and culture. Three areas where Mamanda is performed have been studied using Paul Ricoeur's textual theory. There are two kinds of texts, the Mamanda performance (considered as text, that is, social events fixated in the form of a performance), and the narration of the performance itself which is considered a text as well.
\end{abstract}

KEYWORDS

Mamanda theatre, texts analysis.

\section{INTRODUCTION}

This article rests on my working assumption that there is an affinity between Banjar culture and the Mamanda, namely that Mamanda functions to perform Banjar culture. Therefore, watching and attending performances of Mamanda theatre will improve our understanding of Banjar culture. At the same time, as in Paul Ricoeur's theory (1982), the two levels of a text - the performer as a text, and the text of the performer - becomes more readable if there is sufficient knowledge and understanding of Banjar culture which is the context where the texts have been produced.

The idea about the possible role played by Mamanda for its supporting community originated in my observation of the political situation, particularly of the relation which might exist between government policies and freedom

NINUK KLEDEN-PROBONEGORO is a researcher at the Center for the Study of Society and Culture of the Indonesian Institute of Sciences (Pusat Penelitian Masyarakat dan Kebudayaan, Lembaga Ilmu Pengetahuan Indonesia, PMB-LIPI). She is also a guest lecturer in the Anthropology Department of the University of Indonesia and teaches hermeneutics. Her interest in oral traditions led her to study the Lenong and Topeng Betawi from Jakarta as well as Teater Mamanda and Kemidi Rudat from Lombok on which she has published extensively. Ninuk Kleden-Probonegoro may be contacted at: nnkleden@yahoo.com.

(c) 2010 Faculty of Humanities, University of Indonesia 
of theatrical expression, and the local knowledge which the narratives of the legend revealed regarding the value system and the social-political conditions. Foulcher argues that in watching a performance, one can learn about how governments attempt to make use of theatre performances to justify the exploitation of local people (Yampolsky 1995: 700-725). Acciaioli contends that government policies on performing arts aim to domesticate local people in areas where the government wants them to be (Yampolsky 1995: 714). However, there are also other researchers such as Jennifer Lindsay (1995: 656-671) who elucidates that there is a symbiotic relationship between the government as agent of social change and local traditions including theatre as a place where social change takes place. The question I raise in this paper is rather in line with the previous group of researchers, namely: what relationship does exist between the government and Mamanda or with traditional theatres in general.

There is also a mental association between a theatre performance and its communities. The narratives of a theatre, being treated as a text, can therefore hint at social and political conditions as shown by Peacock (1968) who looks at ludruk (a traditional theatre from East Java) as rites of modernization. My study about the narrative of Topeng Betawi reveals that there is a value of poorness in the Betawi's culture (Kleden-Probonegoro 1987). In the same vein, in this paper, I would like to unveil, to explicate, and to make readable what are being performed in a performance, and what theatre asserts about what the Banjar people really are.

\section{PAUL RICOEUR: THE METHOD OF UNDERSTANDING TEXT ANALYSIS}

This paper builds on the method developed by Paul Ricoeur, a philosopher engaged in various concepts of texts. In this paper, text in its literal meaning refers to the narratives of the Mamanda performance, and the social phenomena which are treated as texts in the Mamanda performance and social environment. The text analysed by Ricoeur derives from the concept of understanding that originated from Wilhelm Dilthey (in Rickman 1979). According to Dilthey, understanding is an intellectual process that can be activated to comprehend the human world in an academically responsible manner.

As a concept, understanding has three different aspects; (i) understanding can be defined as an effort to achieve "something" (or meaning) that can be observed in oral discourse and achieving "something" in written discourse, (ii) understanding can also be defined as knowing an idea or a feeling that is expressed by a resource person, writer, artist, director, and others, and (iii) understanding is also often defined as successfully coming into someone's mind (in this case we think about what Mamanda are thinking about during their play). These three aspects have a high degree of interdependence and must be considered carefully in research methodology.

The concept of understanding as used in the methodology of the humanities, including in analysing Mamanda, must contain criticism that materializes in the validity of knowledge, in the interdependence of 
experience, and also between experience and self-understanding. The criticism occurred because understanding is achieved through the process of induction, analysis, construction, and comparison. In this sense, anthropology is able to use understanding as research methodology. At the same time, understanding can also be treated as part of its research object, namely the purpose to discern the meaning of the narrative shown by Mamanda. In other words, there must be a distinction between "understanding" as a concept and "understanding" as a methodology (to understand the concept of understanding).

The methodology of understanding of texts as briefly explained above will be applied to analyse Mamanda. As other texts that can be re-read and have references, Mamanda in this paper also has two forms of texts which are the performance and the narrative. Therefore, by watching Mamanda, we are witnessing Banjar culture as reflected in the title of the paper: "Mamanda theatre: the play of the Banjar culture".

\section{MAMANDA IN ITS GEOGRAPHICAL AND ETHNIC CONTEXT}

South Kalimantan is $40.387 \mathrm{~km}^{2}$ wide which is relatively small compared to other provinces in Kalimantan ${ }^{1}$. Historically, East Kalimantan is occupied by the Banjar people who call themselves Urang Banjar. However, among themselves, they prefer to identify each other by mentioning their district and even their villages. In addition, there are also the terms Orang Hulu or Orang Hulu Sungai for those coming from the upper course of the river, and the Kuala who come from the downstream. Therefore, in general there are two types of Banjar people, the Banjar Hulu and the Banjar Kuala, identities derived from their geographical locations.

Banjar Kuala culture is full of the river which can be observed in their houses, transportation, occupation, and language. Klotok, a boat, is the means of transportation to pass through the river which is treated as the main road. Despite the existence of a land road, most people prefer the river for transportation. The main occupations are related to the river, even the farming which depends on the river's tides. The Mamanda from this area is known as Mamanda Pariuk.

Traditionally, the Banjar Hulu live in an area that is traditionally called Benua Lima since the era of Dutch colonization. Despite the fact that South Kalimantan is divided nowadays into regencies and municipalities, ${ }^{2}$ people continue to recognize Benua Lima as a unity that comprises Tapin, Hulu Sungai Selatan, Hulu Sungai Tengah, Hulu Sungai Utara, and the Tabalong districts. The main occupation in Benua Lima consists of agrarian activities, rice field using the tide mechanism (especially near swamps), the fields in this area are often used to plant rubber trees which was one of the most important

For instance if compared to West Kalimantan $146.762 \mathrm{~km}^{2}$, Central Kalimantan 152.600 $\mathrm{km}^{2}$, and East Kalimantan $204.000 \mathrm{~km}^{2}$ (Riwut 1979).

2 Banjarmasin district (Banjarmasin city), Barito Kuala, Tanah Laut, Kota Baru, Taipin, Hulu Sungai Selatan, Hulu Sungai Tengah, Hulu Sungai Utara and Tabalong which are the partition of the Hulu Sungai Utara district. 
commodities during the Dutch colonization (Tunjung 2004). The type of Mamanda in this area is known as Mamanda Tabau.

\section{MAMANDA AND ITS MALAY ORIGIN}

In the western part of Indonesia, a number of theatres with Malay origin can be found. In fact, to define that those theatres are from the same origin, it is insufficient to observe their physical characteristics only. In addition to the language, one also must observe the mental aspects of the theatre, namely its ideology, and the message conveyed through its narrative. Unfortunately, those mental aspects have not been covered in my research. Therefore, the theatres that are considered to have Malay origins are only based on their physical characteristics such as properties, narratives, and the structures of the performance.

Malay traditional theatres are performed in an arena without specific decorations. The main items used are only tables, chairs and costumes that resemble the clothes of former Banjar aristocrats, and a setting of past kingdoms. Not all these properties are used at once. Usually a theatre emphasizes only one item. Like other performances such as the Wayang Bangsawan, Mak Yong ${ }^{3}$ in the Riau Islands, the Mendu theatre in Natuna islands (Effendi et al. 1994) and West Kalimantan (Effendi 1994), and Kemidi Rudat from Lombok (KledenProbonegoro et al. 2001) $)^{4}$, the Mamanda is performed in an arena. These types of theatres also use tables for their performances. Whereas, Lenong, the theatre of the Betawi people is not performed in an arena but uses tables and chairs as important properties. Topeng Betawi $\mathrm{i}^{5}$ does not use any decorations, is performed in an arena, and uses a table and two chairs. The costumes resemble the clothes of Malay kings with a headscarf knotted in a distinctive way. The headscarf is also known as laung among Banjar people; and is also known in Wayang Bangsawan, Mendu, and Kemidi Rudat. In Lenong Denes which has not been played since the 1950s (but is being revived today), the king also wears a headscarf similar to the above mentioned theatres. The setting of ancient kingdoms is known among Mamanda, Wayang Bangsawan, Mendu, and Kemidi Rudat, yet unseen in Lenong and Lenong Denes. This is not surprizing because the Betawi never had any kingdoms in their history.

These theatres that share the same root recognize two narratives which have been passed down since several generations. Therefore, the names of their writers are no longer known, and the narratives have become popular stories. The main stories of Mamanda are called carang kanda and the second carangan. The former can take the form of 1001 night stories or tales in Mamanda Pariuk

3 Mak Yong has been described excellently by Pudentia in her dissertation defended at the University of Indonesia (2007).

4 We should differentiate between Rudat, which is a form of a dance, and Kemidi Rudat which is a theatre that has experienced a number of changes. In the past it was performed in an arena, but after the political reform in 1998 it has been performed on a stage with decorations to create an atmosphere.

Topeng in Betawi language refers to performance instead of masks as it would be in Bahasa Indonesia. 
(the form of the Mamanda of the Banjar people in Taipin), and the legend of Mamanda Tubau. Stories for the Betawi, Lenong, Lenong Denes as well as Topeng are known as cerita riwayat and cerita karangan, or in other words stories of the authors. A cerita riwayat is a legend for instance "the legend of Bang Pitung". Tales known in Kemidi Rudat are written in Malay and include "Siti Zubaedah", "Hikayat si Miskin", and "Raja Baghdad". According to Tan Sooi Beng (1993) these three narratives are performed in the Teater Bangsawan in Malaysia. Popular tales of Kemidi Rudat such as "Buaya Darat", "Puspasari", "Jula Juli Bintang Tuju" are similarly performed in the Teater Bangsawan. A variation of the "Jula Juli Bintang Tuju" for instance, is the "Jula Juli Bintang Tiga" (Tan Sooi Beng 1993).

These theatres usually introduce the group and the performed narrative in the beginning of the performance. Mamanda, Mendu, and Wayang Bangsawan share similar structures and terminologies. Mamanda uses the term ladon, whereas in Wayang Bangsawan and Mendu the terminology used is ladun. Ladon and ladun refer to the dances and songs that signify the beginning of a performance. In Mamanda, the peladon or the dancers of the ladon must be of odd numbers, usually three - seven. One acts as the leader while the rest consist of pairs. The leader gives the greetings and explains about the performed narrative. This structure is unknown in the Betawi theatre, as is the case in Mamanda Tubau (the Mamanda story of the Banjar people from Hulu Sungai Tengah) which uses the term konon to indicate the beginning of the show. In these two theatres, the leader of the group steps forward with a loudspeaker and introduces the name of each performer as well as the narrative performed. The similarities in properties and narratives among Malay theatres are the reason why those theatres are considered as having Malay roots.

\section{THE THREE FORMS OF MAMANDA IN SOUTH KALIMANTAN}

Bachtiar Sanderta, a director, who has become a Mamanda maestro passed away in 2009. He connected Mamanda with the Komedi Indra Bangsawan. According to his information, in 1897 Komedi Indra Bangsawan came to perform ${ }^{6}$ in Banjarmasin. It was led by Encik Ibrahim bin Wangsa and his wife Encik Hawa. This informant also asserts that the other name of Komedi Indra Bangsawan is Abdul Muluk.

Tan Sooi Beng in her book (1993) neglected the name Abdul Muluk. She only elucidates that Teater Bangsawan had been influenced by Persian theatres in 1880s. Sanderta (Jarkasi 2002) refers to the name of Indra Bangsawan which we can relate to Tan Sooi Beng's writings (1993: 16) which explicate that in 1885 there was a rich Persian in Malaysia who established the Pushi Indra Bangsawan. This group is later known as Bangsawan and can only be found in Singapore. In 1890s the name of Persian-related theatres appeared such as Wayang Parsi, Komedi Melayu and Bangsawan. In the end of the nineteenth century, these types of theatres are also called opera, a name given by the people of the West.

6 The name of Ibrahim Wangsa and his wife Encik Hawa who performed in Banjarmasin is also known by Sattar, a Mamanda director in Samarinda, East Kalimantan. 
I believe that there is a relationship between Parsi, Indra Bangsawan, and Mamanda, although currently there is still a missing link. People believe that Indra Bangsawan came to South Kalimantan and spread the seeds of Mamanda. ${ }^{7}$ However, if we look at the fact that many theatres of Bangsawan origin were spread in the whole Malacca Strait (Tan Sooi Beng 1993: 16), there is a possibility that there was an Ibrahim bin Wangsa who came to Banjarmasin but was overlooked by her. Interestingly, in describing the spread of theatres in South and Southeast Asia by the end of the nineteenth and the beginning of the twentieth century, Tan Sooi Beng shows in her map (1993: 19, map 2.1.) that Banjarmasin was one of the cities where the Teater Bangsawan was performed. Based on the observation of Suderta, in the end Komedi Indra Bangsawan was called Abdul Muluk which influenced the forming of a new theatre known as ba Abdul Muluk or shortened as Badamuluk. Literally, Badamuluk means conducting Abdul Muluk. This Badamuluk is known as the origin of Mamanda, the theatre of the Banjar people.

Mamanda itself comes from the word mama with the suffix -nda which is meant for beloved ones. Mama is an appellation of the word marina which means uncle. In the performance, the word mamanda is used by the king when addressing the Mangkubumi and Prime Minister known as Wazir. They are referred as "Mamanda Mangkubumi" and "Mamanda Wazir".

During its later development, there are three areas where Mamanda is performed. First, there is Mamanda Tubau from the Tubau village in Hulu Sungai Tengah district. Second, there is the Mamanda Pariuk also known as Mamanda Batang Banyu or Mamanda Margasari from the Tapin district. Lastly, there are other forms of Mamanda which look more modern. I call them Mamanda Banjar, a mixture between Pariuk and Tubau with additional new aspects. These kind of Mamanda are often used in festivals in Banjarmasin city. "Mamanda Banjar" has been popularized by the group "Teater Banjarmasin" in cooperation with Taman Budaya. This Mamanda is a sign of modernity for the Banjar people and at the same time is used by the local government as a cultural landmark of the South Kalimantan province.

David Harvey (1998: 21-28) observed that there is a relationship between culture and the local situation where the culture exists. The same occurs in the South Kalimantan landscape that gave shape to the three forms of Mamanda: Tubau, Pariuk, and Banjar.

Table 1 shows that Harvey's assumption is also relevant for South Kalimantan. Mamanda Tubau, which originates in the flat landscape in HSS and HST also has a flat melody. Mamanda Pariuk that comes from an area with undulating rivers has a rising and falling melody.

\footnotetext{
Moreover, the group Pushi Indra Bangsawan also performed in Betawi (Tan Sooi Beng 1993: 13) which I think is the offspring of Lenong Denes and Lenong.
} 


\begin{tabular}{|c|c|c|c|}
\hline & Mamanda Tubau & Mamanda Pariuk & Mamanda Banjar \\
\hline Distribution & $\begin{array}{l}\text { Districts HSS (Hulu } \\
\text { Sungai Selatan) and } \\
\text { HST (Hulu Sungai } \\
\text { Tengah) }\end{array}$ & Tapin district & $\begin{array}{l}\text { Banjarmasin } \\
\text { municipalities, Banjar } \\
\text { Baru district. }\end{array}$ \\
\hline Songs & Flat cadence & $\begin{array}{l}\text { Songs of the nobility } \\
\text { with undulating lilt }\end{array}$ & Flat cadence \\
\hline Entertainment & $\begin{array}{l}\text { Gandut (popular folk } \\
\text { dance) and gambus } \\
\text { (popular folk music) }\end{array}$ & $\begin{array}{l}\text { Gandut (popular folk } \\
\text { dance), instrumental, } \\
\text { Arab songs, regional } \\
\text { songs. Music with } \\
\text { added orchestra and } \\
\text { flute melodies }\end{array}$ & $\begin{array}{l}\text { Gandut, and music with } \\
\text { added orchestra and } \\
\text { flute melodies }\end{array}$ \\
\hline King's costume & $\begin{array}{l}\text { A bandage wound } \\
\text { around the head }\end{array}$ & $\begin{array}{l}\text { A black scull-cap } \\
\text { (kopiah), a plume } \\
\text { of jambunau bird } \\
\text { feathers }\end{array}$ & $\begin{array}{l}\text { A bandage wound } \\
\text { around the head }\end{array}$ \\
\hline King's dance & Move around the table & $\begin{array}{l}\text { While singing and } \\
\text { walking may cover } \\
\text { the whole stage }\end{array}$ & Move around the table \\
\hline $\begin{array}{l}\text { Beginning of } \\
\text { performance }\end{array}$ & $\begin{array}{l}\text { A chairman's speech, } \\
\text { Konon }\end{array}$ & $\begin{array}{l}\text { uses a ladon (type of } \\
\text { character) }\end{array}$ & $\begin{array}{l}\text { uses a ladon (type of } \\
\text { character) } \\
\text { Story and carangan }\end{array}$ \\
\hline Narrative & $\begin{array}{l}\text { Legend and carang } \\
\text { kanda }\end{array}$ & $\begin{array}{l}\text { Story and carang } \\
\text { kanda }\end{array}$ & \\
\hline
\end{tabular}

Table 1. Three forms of Mamanda in South Kalimantan.

Mamanda Pariuk's narratives are crammed with songs, in contrast to Mamanda Tubau. Mamanda Pariuk's songs, similar to its geographical area, which is crossed by winding rivers, also have undulating cadences, while Mamanda Tubau's just have flat cadence. The interval in Mamanda Pariuk are accompanied by sort of popular folk dance (the gandut), with songs with Islamic overtones, and Banjar songs, while Mamanda Tubau makes repeated use of a band in the intervals. The ladon is accompanied by songs and traditional poetry (pantun), and is only found in Mamanda Pariuk. Another distinction is found with the king's position who, at Mamanda Pariuk is accompanied by songs and dance, covering the whole stage, while the king at Mamanda Tubau only stands near a table put there for him.

\section{THE DYING MAMANDA PARIUK}

The Pariuk village located in the Tapin district was initially known as the centre of Mamanda development. However, since 2003 Mamanda Pariuk is no longer known. My research in that period shows that the death of this 
Mamanda was caused by several factors. The first factor is the development of the majelis taklim. In 2003, in this area the majelis taklim had a total of more than 500 members. Seven majelis taklim with 50 members and two majelis taklim with about 100 members. Previously, until 2000 there were only five majelis taklim with 50 members, and there was one majelis taklim with 100 members.

The main activity of the majelis taklim is to hold prayers, and almost every night, including Saturday and Sunday night there are prayers. At the same time, the area's culture prohibited celebrations in the surrounding villages if a prayer is held. ${ }^{8}$ Looking at this, it can be understood that the Mamanda is no longer performed, because the function of Mamanda to gather people has shifted to the prayers held by the majelis taklim.

The second factor is connected with permits to hold festivities. On one hand, according to one Mamanda player, the police (police of the Tapin district) who is in charge of giving permits for festivities, no longer allows night events including Mamanda, because performances are considered to draw commotions. Yet, Mamanda cannot be held during the day time. The shining of the pemandaan clothes, especially the king's costume, will be unseen. On the other hand, the police chief denies this statement. According to him, people no longer ask for permits for festivities because nowadays they prefer to go to the majelis taklim.

The third factor is that the young people prefer to watch single organ performances where an organist plays together with a singer. This kind of performance is also known as karaoke and is often played during weddings. The rising popularity of the single organ has caused the popularity of the Mamanda to drop.

These three factors are the main reasons why the "Gemerlapan" group in Margasari village never performs in its own domicile. The group only consists of the property owner and a relative who stays in his house. The performance can only be done with ngebon pemandaan which is inviting other Mamanda players from other villages. There are only occasional invitations when there is a performance outside the sub-district.

\section{MAMANDA TUBAU AND ITS NARRATIVE}

The explanation above shows that there are three forms of Mamanda: Tubau, Pariuk, and Banjar. All three are different from one another. This analysis is limited to Mamanda Tubau in Hulu Sungai Tengah and Hulu Sungai Selatan.

The people of Hulu Sungai Tengah use Mamanda to celebrate weddings, Independence Day, and to collect funds to repair infrastructure. In this case, there is usually a border for the space of the performance made by ropes. The audience has to pay for the seats prepared by the organizers. Those without a seat pay less than those with a seat.

8 The return of a student of Guru Ijai (who passed away a couple of years ago) who was only 22 years old had an important impact. People believed that he had the guru's charisma. $\mathrm{He}$ is a renowned religious leader from a pesantren in Martapura. 


\section{"PANCAR Rindang BanAWA" (FROM THE Batu BANAWA VILLAGE, HuLU SungaI TENGAH)}

Mamanda in Hulu Sungai Tengah exists among other art performances namely Hadrah, Rebana (both are musical performances), Kuda Gepang (dance), and other forms of theatres such as Kuda Gepang Carita, Wayang Gong (in Java), and Wayang Kulit Banjar.

"Pancar Rindang Banawa" which is better known under its abbreviation "Panrinben", is the only Mamanda group in the area. In the language of Banjar Hulu, pancar means "to spread" and rindang means "protecting". The pemandaan (the local term referring to Mamanda players) from this group live in a number of villages in the Batu Benawa district. This group is not hereditary even though there is a senior Mamanda player who develops his group and teaches the students at a school in Batu Benawa district. This group is spearheaded by a number of pemandaan who are the descendants of former Mamanda players.

"Panriben" has four stories (which have been memorized by the pemandaan): "Bergetarnya Tiang Aras", "Pembaringan Terakhir", "Antara Tugas dan Cinta", and "Pagar Makan Tanaman". The research was only conducted with respect to the first title. "Bergetarnya Tiang Aras" and "Pembaringan Terakhir" are local legends which are very popular. The former is a narrative from the people of Batu Benawa and the later from the Martapura people which is already popular in South Kalimantan. "Antara Tugas dan Cinta" and "Pagar Makan Tanaman" are the creation of local directors. "Bergetarnya Tiang Aras" is considered sacral and people prepare offerings before a performance begins.

The district office of Batu Benawa is only ten $\mathrm{km}$ away from the capital of the sub-district which is Barabai. Around 75\% of its inhabitants are farmers who work in the rice fields or in rubber plantations, same as the pemandaan.

\section{Narrative: "Bergetarnya Tiang Aras"}

This narrative is also known under the title "Raden Penganten sama Diang Insun". The literal meaning of Tiang Aras is a supporting pole known in Banjar cosmology. The main function of this pole is to support the world. If tiang aras falls, the world will fall as well. The second narrative is called "Raden Penganten sama Diang Insun". "Bergetarnya Tiang Aras" shows the cosmology of the Banjar people, "Raden Penganten sama Diang Insun" is a legend which the local people believe to be true.

All Mamanda performances are marked by an opening that in Mamanda Tubau is called konon. ${ }^{9}$ After that, a chapter labeled "Sidang Kerajaan" (the beginning of the kingdom) begins. The chapter starts with two guards guarding the kingdom of "Mandung Marindu" ${ }^{10}$ The two guards are known as

9 It is called konon (once upon a time) because of the beginning "konon adalah sebuah kerajaan bernama $[\ldots]$ " (once upon a time there was a kingdom [...]).

10 The name of kingdoms in Mamanda are always ficticious. 
Harapan Satu (first hope) and Harapan Dua (second hope). They are decorating the palace in order to prepare a trial. Following the scene, the Prime Minister comes into the room and explains how well prepared the room is. All high officials are present; in addition to the Prime Minister, the Mangkubumi, the commanders of the four armed forces, the queen, the sons and daughters of the king, and the Hadam who is the butler of the royal family.

The conversation rests on two topics. Harapan Satu wants that illegal logging is pursued while Harapan Dua wants to be promoted to become Mangkubumi. The Mangkubumi reports about the complaints of the peasants about the fluctuating prices. He thinks that there must be a solution to stabilize the price of rubber. The last scene of this chapter is a feast in the palace accompanied by orchestra and singers. "Mandang Marindu" is celebrating the anniversary of the kingdom which falls on 17 August. ${ }^{11}$

In the village far away from the kingdom, there was a poor widow with her son Naro who wanted to leave in order to seek a better life. Naro worked as a gardener of the palace. The king's daughter Maharani fell in love with him and wanted to marry Naro. However, the king did not approve of her request until one day Naro stopped a robbery and saved the queen from falling victim. The king felt he was indebted to him and allowed his daughter to marry Naro who then received the royal title Raden Penganten.

One day Raden Penganten conducted an inspection in the villages using a ship, and he set sail in the village where he grew up. Diang Insun who already became old called out to her son, but Naro did not acknowledge her. Diang Insun was disappointed, sad, and angry and she said. "If you are truly Naro my son ... then turn to stone", and the miracle happened. Naro, his wife, and all the crew of his ship turned to stone.

The ship of Raden Pengantin was divided in three. The front part of the ship can be found in Laki-Bini (husband-wife) mountain in Kandangan, Hulu Sungai Selatan district. The center part of the ship is now located in Liang Halangan mountain (Liang means cave), right behind Desa Murung A. In the cave there is a bed, mosquito net, utensils, and a gong which are made of stone. If one hits the gong, the sound that comes out is similar to an ordinary gong. The rear part of the ship is located nowadays in Desa Batu Benoa.

\section{"Permata" (From Jelatang Village, Hulu Sungai Selatan)}

In this district "Permata" which is a Mamanda Tubau is not the only Mamanda group. There are other Banjar type groups which are more modern. This group is in the district's capital, Kandangan, and is managed by its Art's Council. "Permata" is being analysed because it has the same roots as Mamanda Tubau.

The Jelatang village in Padang Batung sub-district, Hulu Sungai Selatan, is located $8 \mathrm{~km}$ from Kandangan. The area is mountainous (compared to relatively flat Kalimantan) and is passed by the huge Amandit river. The main

11 The purpose of the performance is to celebrate Indonesian Independence Day on 17 August. 
occupation of the inhabitants of the village is farming which includes planting paddy in rain cistern rice fields, and planting rubber trees. In addition, they are also known as palm sugar vendors for the traditional markets in South Kalimantan.

The name "Permata" is an abbreviation from "Persatuan Masyarakat Tani" (the association of farmers) because all of its members are farmers. The group has been established a long time ago and all its members are related to one another. Genealogically, pemandaan is always patrilineal. Therefore, women characters are men in female clothing. Women players only emerged in the last couple of years.

The group leader who during the interview was 65 years old admitted that he has been an active member of the group since he was 17. At that time the group was led by his father who took over from his grandfather. Roughly, it can be estimated that the group has been established about 100 years ago, because his grand grandfather was already a Mamanda player in the same group. However, the name might have changed over time. The name "Permata" has been used since the grandfather led the group. The properties used are already worn-out, nevertheless this does not reduce the enthusiasm of the people of Hulu Sungai Selatan. The "Permata" group performs in almost all wedding ceremonies.

The narrative of the "Permata" is created by a director based on his observation of people's daily lives which can be seen in the play "Dibalik Tirai Penghalang" and "Pudarnya Cinta karena Harta". In addition, "Permata" also often adopts a narrative that has been played over the radio, for instance "Batu Laki, Batu Bini" (the masterpiece of the Mamanda maestro Bactiar Sanderta who lived in Banjarmasin at that time).

\section{Narrative: "Dibalik Tirai Penghalang"}

The first chapter of the performance in Jelatang does not start in a palace ambience; rather, the setting is a common village. There was a poor family consisting of a father, mother, a daughter, and a son. The mother was always financially unsatisfied and demanded more money from her husband than he could afford. One day a rich merchant employed her and she left her family to work for him. Not long after, she was made his wife.

Meanwhile, her husband and children lived in destitution. The old husband who was blind was not able to provide a proper living for his children and asked them to beg. One day the children were lost. The boy was taken up by a family who had a daughter, and he was given the name Kelana. Several years later the daughter had grown into a pretty woman and fell in love with Kelana and wanted to marry him. She explained that they are not brothers and sisters. Hearing this Kelana left and looked for his family.

The next chapter tells the story of the daughter of the blind man who went astray into a palace and was appointed to become princess. One day the princess went to a garden and met Kelana who became gardener. The two fell in love, despite Kelana's warning that they are not of the same status. Yet the 
princess was adamant, and as a result Kelana was tortured by the Commander in Chief and Harapan Satu until he fell unconscious. The princess assisted him to gain consciousness and ran away.

The third chapter explains about the merchant who was in disharmony with his wife. They had a fight and the merchant sent off his wife without providing any property. The woman went without direction and met Kelana and his future wife in the forest. She asked them where they are going, and they explained that they were planning a run-away wedding. Recognizing her children by their birth marks she prevented them from getting married, hugged them and told them that they were her children. The three went to seek the blind father, and the family reunited.

\section{THE BANJAR MAMANDA: TUBAU AND PARIUK IN CURRENT ISSUES}

The Banjar Mamanda ${ }^{12}$ which performance is a combination of the Tubau and the Pariuk is known in the Banjarmasin municipality, Banjar Baru district, and Banjar district. In Banjarmasin, which is the capital city of the South Kalimantan province there is a Mamanda group that is managed by Taman Budaya (cultural association). The group became independent and called themselves "Teater Banjarmasin". This group, which is the origin of Mamanda, is managed by a number of researchers from the Lambung Mangkurat University who have special attention for traditional theatres, former leaders of Taman Budaya who were Mamanda players in their youth, and artists from Taman Budaya. Therefore, it is unsurprizing that this group is the pioneer of changes in the play which are followed by other groups.

In Banjarmasin, groups from various areas in South Kalimantan often participate in Mamanda festivals. "Incidental" groups consisting of students of the Lambung Mangkurat University also take part in the festivities. The festivals are often held to celebrate Independence Day on 17 August and other national holidays. Such groups only perform occasionally and take the name of their faculties, for example, "The Mamanda Group of the Law Faculty".

The Banjar Baru district has been known for its reputation of holding Mamanda celebrations. Many Mamanda artists also live in this area. For instance Nanang Rivoli, a pemandaan figure, has been living there since the New Order era. One of the Mamanda group from the Banjar Baru district is the "Teater Rantai".

Whereas in the Banjar district, which borders the Tapin district where Martapura is located, people are no longer accustomed to watch Mamanda. There is also no pemandaan group in this area. However, we can still see Mamanda in the Banjar district, except in the Sekumpul village due to the influence of Guru Ijay who shifted the attention of the villagers towards Muslim prayers. The author has seen Mamanda in the Rengas Hambuku

12 The name Banjar Mamanda is given by the author. The respondents in the research location do not know this type of Mamanda. People only mention the places where they are held such as Banjarmasin, Banjar Baru, or Martapura. 
village, yet the players come from the Banjar district.

The narrative of the Banjar Mamanda comes from the group of the Law Faculty of the University of Lambung Mangkurat in the Banjarmasin municipality and a narrative of the "Teater Rantai" from Banjar Baru district.

\section{"GRUP FAKULTAS HUKUM” (FROM BANJARMASIN MUNICIPALITY)}

The "Grup Fakultas Hukum" (the Law Faculty Group) performs usually on 17 August in a Mamanda Festival that is held to celebrate the Independence Day of Indonesia. Like other university Mamanda groups they only perform occasionally. The festival is considered to be the best forum to display one's ability. Therefore, faculty groups perform only once or at most twice a year.

\section{Narrative: "Busa Atawa Bumiku Satu"}

The performance is started by seven Baladun $n^{13}$ (in Bahasa Indonesia ber"ladun"). Before the trial of the palace, Harapan Pertama and Harapan Kedua were discussing a pay rise. In the trial of the kingdom Banjarsari, which was attended by all staffs of the palace, the king inquired about the problems faced by the kingdom. The Commander in Chief asked the king to cancel the ban of trucks carrying coal through the villages within the kingdom. The king refused because the heavy trucks could damage the roads. Shortly after, the Hadam, the butler of the prince and the princess enter the stage and explain that in his village, the forests and mountains were destroyed because the trees had been cut by people from the city. In addition, coal mines were also obliterating the fields. The king confirmed the destruction of nature to his son, Indra Buana, who did not believe the report. Therefore, the Commander in Chief recommended the prince to conduct an inspection to the villages. The prince went with the Commander in Chief.

In one village there was a husband and wife who together with the village teenagers were concerned about the distruction of their nature. They agreed to report the circumstances to the king. However, on their way they were robbed by robbers. In the middle of their argument, the prince and the Commander in Chief came along. It turned out that they are the allies of the robbers. The villagers managed to escape to the palace. Shortly, Indra Buana and the Commander in Chief arrived and accused the villagers for rioting. The king who understood that his son and his Commander in Chief were cooperating with the robbers, extracting the coal, and destroyed the forest put a punishment on them.

\section{“TEATER RANTAI” (BANJAR BARU DISTRICT)}

Unlike the pemandaan from the law faculty, the members of the "Teater Rantai" are former officials of the sub-district information office (under the district information office). Humaedi, the group's leader is an alumnus of the theatre academy in Banjar Baru. He is not someone from an artist lineage, and he has 
been leading the group since the New Order era. At that time the government used "Teater Rantai" to socialize its policies. However, it was also used to celebrate wedding ceremonies.

In the Reform era, after President Abdurrahman Wahid dissolved the Department of Information, the "Teater Rantai" performs only from time to time, including during celebrations of Independence Day. All members of the "Teater Rantai" have enjoyed a certain level of education. The lowest level of education among them is high school.

\section{Narrative: "Juragan Wahid"}

The first scene does not use ladun but there are Banjar songs and dances. The following scene is about a situation in Kadamengan Gasing Kemuning which is led by Demang ${ }^{14}$ Seta. He had tens of fish fonds managed by Mail, his staff. One day he received a letter from Temanggung saying that he is going to send his staff to the Demang's Kademangan. Demang Seta intended to entertain the guest with dances and by offering him his fish. However, before the fish were taken from the pond, it turned out that they were all dead. Demang Seta was surprised and did not know what to do. His wife and Mail recommended buying fish from Juragan Wahid, a successful fish seller in Kademangan Gasing Kamuning. Demang Seta agreed.

At the same time, Juragan Wahid in his house was angry with his subordinate named Samad for borrowing the fish he was supposed to bring to Kotaraja to one of his people. During his outburst, his wife arrived and asked for permission to dance in Kademangan. When Demang Seta arrived with his family the situation was tense. Abruptly, the Hulu Balang Ketemanggungan who was supposed to meet with Demang Seta also arrived. His main purpose was to inquire about the water pollution in the vicinity of Kedemangan Gasing Kamuning which had already polluted the water in Kotaraja.

After the investigation, it turned out that the crux of the problem was Juragan Wahid who caught his fish using the Tuba root, a specific root that could kill the fish and pollute the water. The Hulu Balang Ketemanggungan stated that Juragan Wahid had destroyed the environment, and was therefore subject to being sentenced.

\section{TEXT ANALYSIS: FROM PAUL RICOEUR TO THE BANJAR CULTURE}

In the case of Mamanda, the text analysis of Ricoeur has two forms. The first is the performance as a text, including the Mamanda group, artists and the audience, ${ }^{15}$ and second, the text as the performance (the narrative of the text). First, I will treat a performance as text, as Ricoeur treats social phenomena. Those phenomena are classified in the form of texts. Reading the text in this manner is similar to reading the narrative of the writer.

The writers of the texts are none other than the Banjar people, including

14 Kademangan is a form of traditional governance in Banjar under the Tumenggung. A kingdom consists of a number of Ketemanggungan.

15 See Ricoeur $(1982,1986)$. 
the writer of the script whose writing is often influenced by the director. The text is then expressed into a performance of the group and the artists. In the case of the Mamanda Pariuk, the Banjar people (Tapin district) no longer want Mamanda, they do not want to write Mamanda, meaning that no more performance is needed. In other words, in this area Mamanda died. The people of Hulu Sungai Tengah and Hulu Sungai Selatan still write Mamanda until today. The old and worn Mamanda is still a favorite. While in Hulu Sungai Selatan, Mamanda was revived by an old artist who taught the youth in Batu Benawa village. This can be understood as a search of identity through Mamanda. Borrowing Hobsbawn and Ranger (1983) terminology, the people of Hulu Sungai Selatan conducted a revival to revitalize a Mamanda that had not been seen for a long time, in its original form as is known in the tradition of Hulu Sungai Tengah (Banjar). Using Ricoeur's framework, this means that the people of Hulu Sungai Tengah are re-writing an old story (literally and metaphorically).

Second, the analysis of the narrative of the performance which is treated as text has the purpose of grasping the meaning of the text, including the idea and feelings of the Banjar writers, directors, and young players. The Banjar people are considered text writers because the content of the script does not deviate from Banjar culture. This is one form of traditional narrative. It would be impossible that the meaning of the narrative of Ronggeng Dukuh Paruk by Achmad Tohari and the setting of the Dukuh Paruk village could appear in Mamanda. Similarly, the narrative of the Lenong, a Betawi theatre which implicitly has its setting in Betawi culture, could not emerge in Mamanda. This is the assumption of this paper which understands that there is an affinity between Mamanda and the Banjar culture as explained in the introduction.

In addition to that, Ricoeur also explains that the reader of a text is believed to understand the text when the person successfully enters the thinking behind the text. In this case, when we think what Mamanda thinks in its performances. According to Ricoeur, one method of understanding the text is through structure ${ }^{16}$ The narrative is analysed through chapters, scenes, and dialogues which can be summed up through the journey of the main character. Table 2 summarizes the reading of the text.

The first issue to be analysed is the type of the narrative. The four narratives in Table 2 show that there are two groups of narratives, legend and carangan (cerita karangan or fiction), and that both tell about the lives of human beings. In observing the main characters we can conclude that these two forms rest on the live experience of the poor. In Hulu Sungai Tengah, there was Naro (legend) who decided to move out to earn a better living. In Hulu Sungai Selatan, there was Kelana (carangan) coming from a truly destitute family. The mother decided to marry a rich merchant, the father became blind, and Kelana was separated from his sister. Other stories in carangan are about today's issues and are told by the Banjar Mamanda. The character of Indra Buana turns out

16 Ricoeur who believes in post-structuralism considers structures important, though meaning is not derived from structure only, as is in language. 
to be in alliance with the robbers in the narrative "Busa Atawa Bumiku Satu", while the story of "Juragan Wahid" tells about environmental damage. The issue of corruption among Soeharto's sons had inspired the writer, as well as the environment that must be protected.

\begin{tabular}{|c|c|c|c|c|c|}
\hline District & Narrative & Setting & Main Character & Plot & Ending \\
\hline HST & $\begin{array}{l}\text { "Bergetarnya } \\
\text { Tiang Aras" }\end{array}$ & $\begin{array}{l}\text { village - } \\
\text { kingdom }\end{array}$ & $\begin{array}{l}\text { Naro, village } \\
\text { teenager }\end{array}$ & $\begin{array}{l}\text { Naro marries } \\
\text { princess }\end{array}$ & $\begin{array}{l}\text { Turn to } \\
\text { stone }\end{array}$ \\
\hline HSS & $\begin{array}{l}\text { "Di Balik Tirai } \\
\text { Penghalang" }\end{array}$ & $\begin{array}{l}\text { village - } \\
\text { kingdom }\end{array}$ & $\begin{array}{l}\text { Kelana, village } \\
\text { teenager }\end{array}$ & $\begin{array}{l}\text { Dating, Kelana } \\
\text { - princess. Not } \\
\text { married. }\end{array}$ & $\begin{array}{l}\text { Reunited in } \\
\text { village. }\end{array}$ \\
\hline $\begin{array}{l}\text { Banjarmasin } \\
\text { municipality }\end{array}$ & $\begin{array}{l}\text { "Busa Atawa } \\
\text { Bumiku Satu" }\end{array}$ & $\begin{array}{l}\text { kingdom - } \\
\text { village }\end{array}$ & $\begin{array}{l}\text { Prince, Indra } \\
\text { Buana }\end{array}$ & $\begin{array}{l}\text { Indra Buana } \\
\text { and Com- } \\
\text { mander in } \\
\text { Chief ally with } \\
\text { robbers. }\end{array}$ & $\begin{array}{l}\text { Prince and } \\
\text { Commander } \\
\text { in Chief } \\
\text { punished. }\end{array}$ \\
\hline $\begin{array}{l}\text { Banjar } \\
\text { district }\end{array}$ & $\begin{array}{l}\text { "Juragan } \\
\text { Wahid" }\end{array}$ & $\begin{array}{l}\text { Kademangan } \\
\text { - Temang- } \\
\text { gungan }\end{array}$ & $\begin{array}{l}\text { Demang - } \\
\text { Juragan Wahid }\end{array}$ & $\begin{array}{l}\text { Environmental } \\
\text { damage. }\end{array}$ & $\begin{array}{l}\text { Juragan } \\
\text { Wahid } \\
\text { punished. }\end{array}$ \\
\hline
\end{tabular}

Table 2. Text analysis of the Mamanda performance.

Looking at Table 2, Mamanda has the setting of previous eras, the setting of kingdoms are dominant. The variation occurred from time to time as in the narrative "Juragan Wahid" from the Banjar district, the narrative is located in the space of the Kademangan-Temanggungan, an area in the kingdom. ${ }^{17}$ However, the relationship between the kingdom and the village can still be observed in the monologue of Juragan Wahid who was worried about the arrival of the king. Moreover, a number of other narratives from this group still use kingdoms as its setting. For example, in "Tinta Emas" (from the "Teater Rantai" group in Banjar district), the setting is in the Dutch colonial era. The kingdom of Manggala Sakti tried to beat the Dutch who conquered the area. Thus, the factor of kingdom is still significant.

The structure of the performance also merits some attention, because it is the space for the journey of the main character. Generally, the relationship between the palace and the village is strained, and it can even be said that no relation has succeeded. In "Bergetarnya Tiang Aras", Naro who married the princess did not have a long lasting marriage, because at the end of the story, both turned to stone. Kelana in "Dibalik Tirai Penghalang" could not marry the princess because they were siblings. In "Busa Atawa Bumiku Satu" the relationship between the palace and the village was in disharmony not due to a marriage but because of the corruption of prince Indra Busana and the Commander in Chief. By the end of the story, Indra Buana was punished by the king.

The narrative "Busa Atawa Bumiku Satu" was performed during a festival

17 I saw two other performances by the "Teater Rantai" group using the setting kingdomvillage. 
to celebrate Independence Day in 2000, two years after the political Reform. At that time, the case of corruption by Soeharto's children was brought up. What occurred here was that the director from the student group took over the political situation in Indonesia. The bravery of the king in punishing the corruptors signified the students' dream of punishing corruptors, including Soeharto's children. In "Juragan Wahid" which took place in the Kademangan and Katemanggungan areas under the administration of the kingdom, Juragan Wahid was punished for causing environmental damages. The environment is a new policy that the government tries to implement.

\section{CONCLUSION}

At the start, this paper explains that the analysis of Mamanda has the purpose to explicate and to make readable what is being performed in a performance, and to understand who the Banjar people really are in their daily life as is shown through theatre. There are two forms of texts that are analysed here. The first is the performance, in this case social phenomena which are treated as a text, and the text of the performance in the form of narrative. These two forms of texts influence the quality of the bond between Mamanda and Banjar culture. First, text in the context of social phenomena that is fixated as text, shows that the relationship between the Mamanda performance and Banjar culture exists in the social system. Mamanda Pariuk is neglected in its area, the Tapin district, because of the development of Islam in the area, and also because of the government's restriction to conduct night-time festivities.

Mamanda Tubau survives in Hulu Sungai Tengah because the old artists packages Mamanda in a way that is acceptable to young people. There are many teenagers in Hulu Sungai Tengah who want to become pemandaan. This can be observed from the emergence of the Mamanda Banjar with players that include young people such as students. Therefore, Mamanda Banjar always presents current issues. Moderate Mamanda figures such as Bachtiar Sanderta also influence changes in the form of Mamanda (see Jarkasi 2002). He fused Mamanda Tubau and Pariuk and shortened the performance to only two or half an hours during festivals.

Second, texts are narratives and I coin the relationship between the narrative of Mamanda with the culture and the people of Banjar as an affective affinity that exists in the value system. There are a number of symbolic aspects that need special attention namely the kingdom, and the behaviour of the main characters. In general, kingdoms in Mamanda are given fictious names. "Juragan Wahid" is the only performance where the kingdom is only mentioned but not used as a setting. What is the crucial importance of kingdoms?

The kingdom of Banjar already existed during the Hindu era. There are two sources which discusses the Banjar kingdom during the Hindu era, namely Hikayat Lambung Mangkurat also known as Hikayat Banjar, and Tutur Candi that explains about the pedigree of the Banjar kings and the Waringin city. Gazali Usman (1989: 22-23), a Banjar historian asserts that the character of Banjar culture is formed in three periods related with the development of 
various kingdoms in South Kalimantan.

The first period, as explained in Hikayat Banjar, occurred during the time of the most ancient kingdom in South Kalimantan, namely the Tanjungpura kingdom also called Tanjungpuri. This kingdom is believed to have been located in the city of Tanjung today which is the capital of the Tabalong district. At that time, to be precisely in the seventh century, there was a migration of Malay people from the kingdom of Sriwijaya in Sumatra to South Kalimantan. The second period arose during the period of the Dipa kingdom which emerged in the thirteenth century in Amuntai. The third period giving shape to Banjar culture is the period of Islam. The kingdom was established by Prince Samudra, a political refugee who was exiled by Prince Tumenggung, the last king of Daha. The independent kingdom of Muslim Banjar endured until 1865 when the Banjar war ended. In this period, there was an intensive Islamization that resulted in the identification of Banjar people as Muslim. Even the Dayak people who had become Muslim were also considered as Banjar.

The short story of the Banjar kingdom shows that in these three periods, the kingdom played an important role in shaping the Banjar people as mentioned by Gazali Usman. Since the seventh until the thirteenth century, people knew about the Hindu kingdom. It was followed by the emergence of the Islamic kingdom. Interviews with societal leaders and the Mamanda players show that the aspect of kingdoms cannot be neglected. If there was a Mamanda setting without a kingdom they would say "It is not Mamanda". Mamanda has certain values that must be maintained by the Banjar people.

The most important value is respect for the king. What has been decided by the king must be obeyed, because he arrived at his decision through consultation with his advisors known as wazir in the local language. Another form of respect is that the king is free of critics. This can be seen in "Bergetarnya Tiang Aras" where the king initially disapproved of the wedding of his daughter with Naro, though he changed his mind over time. Unfortunately, the half-hearted blessings resulted in Naro's marriage ending in disharmony. Current leaders are like kings. They should not be criticized. Yet, in "Busa Atawa Bumiku Satu" the student group created a plot where the prince was punished. This shows a deviation from established patterns.

All the explanations above illustrate how the audiences of Mamanda performances are actually watching a Banjar culture put into a performance. Conversely, those audiences who do not understand Mamanda also lack understanding of the Banjar culture.

\section{REFERENCES}

Effendy, Bisri. 1994. "Teater rakyat Mendu di Natuna", in: Bisri Effendy, Pudentia MPSS, and Sutamat Arybowo, Penelitian sastra Melayu; Buku 2: Seni pertunjukan rakyat di kepulauan Riau, pp. 9-96. Jakarta: Pusat Penelitian dan Pengembangan Kemasyarakatan dan Kebudayaan, Lembaga Ilmu Pengetahuan Indonesia. [Laporan hasil penelitian Proyek Pengkajian Strategi Sosial Budaya Indonesia, 1991/1992.] 
Effendy, Bisri; Pudentia MPSS, and Sutamat Arybowo. 1994. Penelitian sastra Melayu. Jakarta: Pusat Penelitian dan Pengembangan Kemasyarakatan dan Kebudayaan, Lembaga Ilmu Pengetahuan Indonesia. [Laporan hasil penelitian Proyek Pengkajian Strategi Sosial Budaya Indonesia, 1991/1992.]

Harvey, David W. 1998. Social justice in the city. London: Edward Arnold.

Hobsbawn, Eric and Terence Ranger (eds). 1983. The invention of tradition. Cambridge: Cambridge University Press.

Jarkasi, 2002. Mamanda; Seni pertunjukan Banjar; Dari realitas tradisional ke kesenian populer. Banjarmasin: Dewan Kesenian Kalimantan Selatan.

Kleden-Probonegoro, Ninuk. 1987. Teater topeng Betawi sebagai teks dan maknanya; Suatu tafsiran antropologi. PhD thesis, University of Indonesia.

Kleden-Probonegoro, Ninuk; Yekti Maunati, and Yasmin Zaki Sahab. 2001. Kesenian di Lombok; Representasi dominasi etnik. Jakarta: Pusat Penelitian Kemasyarakaran dan Kebudayaan, Lembaga Ilmu Pengetahuan Indonesia.

Lindsay, Jennifer. 1995. "Cultural policy and the performing arts in Southeast Asia", Bijdragen tot de Taal-, Land-en Volkenkunde 151/4: 656-671.

Peacock, James L. 1968. Rites of modernization; Symbolic and social aspects of Indonesian proletarian drama. Chicago: University of Chicago Press.

Pudentia MPSS. 2007. Hakikat kelisanan dalam tradisi Melayu Mak Yong. PhD thesis, University of Indonesia.

Rickman, H.P. 1979. Wilhelm Dilthey; Pioneer of the human studies. Berkeley, Los Angeles: University of California Press.

Ricoeur, Paul. 1982. Hermeneutics and the human sciences; Essays on language, action and interpretation. Translated into English with an introduction by J.B. Thomson. Cambridge/London/New York: Cambridge University Press.

Ricoeur, Paul. 1986. "Life; A story in search of a narrator", in: M.C. Doeser and J.N. Kraay (eds), Facts and values; Philosophical reflections from western and non-western perspectives, pp. 59-70. Boston: Nyhoff.

Riwut, Tjilik. 1979. Kalimantan membangun. Palangkaraya: n.n.

Tan Sooi Beng. 1993. Bangsawan; A social and stylistic history of popular Malay opera. Singapore: Oxford University Press.

Tundjung. 2004. Karet di Hulu Sungai; Budidaya, perdagangan dan pengaruhnya terhadap ekonomi di Kalimantan Selatan, 1900 -1940. PhD thesis, University of Indonesia.

Usman, Gazali. 1989. Urang Banjar dalam sejarah. Banjarmasin: Lambung Mangkurat University Press.

Yampolsky, Philip. 1995. "Forces for change in the regional arts of Indonesia", Bijdragen tot de Taal-, Land-en Volkenkunde 151/4: 700-725. 